CHURCH BRIEFS IN ENGLAND AND WALES FROM ELIZABETHAN TIMES TO $1828^{1}$

Histories of early modern English poor relief devote much attention to the origins and development of a nationwide system of compulsory rating at the level of the parish, arguably the single most important development in Western welfare provision between the dawn of Christianity and the twentieth century. Building on existing parish-based benevolence, royal injunctions and a statute of 1552 (5 and 6 Edward VI, c. 2) created a novel framework for parishes to raise and store funds, acquired from the wealthier parishioners after Sunday services, for regular distribution in the following week. In 1552 collectors of the poor took over the charitable functions formerly performed by churchwardens, handing over from 1598 to overseers under the supervision of JPs; legislation of 1598 and 1601 made it obligatory to raise money through taxation on inhabitants occupying land in the parish. Overseers' accounts of taxation and disbursement are at the heart of some excellent local and regional studies. Historians have looked closely at the parish, dissecting the often narrow geographical remit of collecting and distributing funds, and stressing that much of the practical implementation of the poor laws was about exclusion as much as inclusion. ${ }^{2}$ The system so created was parochial both in being confined to a narrow area and limited in scope.

All recent studies nevertheless recognise two things. First, that Christians had a wider conception of charity than just those who lived close-by or were familiar. Second, that helping the needy comprised a complex patchwork of provision, in which voluntarism continued to play an important part, even after the Elizabethan poor laws. The sources for voluntary giving and receiving are, however, less tractable and it can be hard to generalise about benevolence which may leave little trace. One under-researched source which can illuminate this dimension of charity - as well as revealing the political and ethical context of collecting and giving money - is known by such diverse titles as Kings' or Queen's Briefs or Letters, Orders in Council, Patents of Alms, Letters Patent, Fire Briefs, Church Briefs, Charity Briefs, Commissions, Royal Letters, and so on. A brief can be a short writing or epitome, such as an abridgment of a law case, made out for instruction to counsel, or indeed any short statement of facts; it is also any writ or precept from the monarch. There are also 'Apostolical Briefs', addressed to princes or magistrates, respecting matters of public 
concern. Medieval popes issued bulls to raise money for the Crusades and the rebuilding of churches and the post-Reformation English briefs, which form the core of this article, resemble these pontifical letters of authority. ${ }^{3}$

As head of the Church of England, the Crown or, more usually from 1547, the Lord Chancellor or the Keeper of the Great Seal, replaced the Pope (or bishop or archbishop), issuing Letters Patent (open letters expressing the sovereign's will on a variety of matters of public interest) authorising recipients to make requests for donations to specific good causes from a particular area in a given period of time. They were one of a variety of documents that fell within the generic category of collection briefs, issued by anyone in authority from the monarch downwards. ${ }^{4}$ Less about the locality and linear boundaries that were the focus of parochial relief, briefs applied to any deserving Christians who could be construed as 'objects of charity', wherever they originated and wherever they lived. They illustrate a broader conception of benevolence than appears in much of the literature on poor relief. And they trace a parallel (if ultimately diverging) trajectory to the growing centrality of compulsory rating for parochial relief from Elizabethan times. Along the way they show change over time in both the philosophy and practices of government, especially in the post-Restoration era and beyond.

To explore these issues, this article uses two archives of issued briefs: 367 letters or 'dockets' in the Huntington Library covering the period 1592-6 and the Crawford collection in the National Library of Scotland, comprising 623 briefs, 1755-1827. These collections are unusual in being consolidated and accessible sets that allow both quantitative and qualitative analysis of original documents. By comparing their form, numbers, content, and coverage we can chart change over time, whereas most existing studies deal with only one of Tudor, Stuart, or Hanoverian briefs. At the more local level many collections on briefs can be found noted among parish register entries or in separate volumes kept by the parish; our knowledge of seventeenth and early eighteenth century briefs is based largely on these. ${ }^{5}$ Dozens of these have been published, providing additional examples and some statistics, notably about amounts collected. Additional sources like diaries and account books help to contextualise briefs' reception and implementation, showing the workings of that mix of personal choice, obligation, moral imperative, and pragmatism, which lay behind early modern English poor relief. 
Early modern briefs were usually single calls for help with a financial loss or shortfall in the life of an individual or community. They solicited aid for a wide range of issues that required remedy: the wives and families of those held captives by the Moors; individuals who had suffered disastrous loss from natural causes such as shipwreck, plague, flood, hail, or fire; manmade losses by robbery, fraud, or warfare; assistance for persecuted Protestants on the continent; helping the poor and afflicted - or new capital spending on good works such as rebuilding and repairing churches, harbours, bridges, hospitals, and houses of correction. Discussed and criticised, yet widely used throughout their existence, they were largely forgotten for two generations after their abolition in 1828, worthy of inclusion in antiquarians' parish histories only for their curiosity value. Then in 1896 barrister Wyndham Bewes published the first and only book on the subject. ${ }^{6}$ His work built on a pioneering article of 1882 by Cornelius Walford, 'an authoritative writer on insurance and actuarial affairs ... [and] [a]n active historian' . ${ }^{7}$ The article offered valuable classifications, but was almost exclusively qualitative and illustrative.

Walford summed up the idea of briefs as follows: 'By their aid the losses of the few could be relieved or mitigated by the contributions of the many. ${ }^{8}$ Most commentators see briefs as remnants of earlier forms of parish funding or as imperfect solutions to problems of guarding against loss that would ultimately be resolved by more rational and efficient means. On the latter count, and ever since debates on their abolition began in earnest in the late eighteenth century, briefs have been regarded as a forerunner of insurance (especially against loss by fire), offering a solution suited to a more personalized and less bureaucratic age. ${ }^{9}$ Over the last half century articles and a handful of theses have focused on the political and ecclesiastical dimensions of briefs, including church building and the support of international Protestantism. ${ }^{10}$ They have also been mentioned cursorily in studies of poor relief ever since E. M. Leonard. ${ }^{11}$ Steve Hindle sees them as a continuation of help- or bidales, communal drinkings held occasionally to raise funds for the needy, which flourished in the fifteenth century only to be abandoned by the end of the sixteenth. ${ }^{12}$ Marjorie McIntosh explains in depth their early uses by individuals and groups, notably for the upkeep of Elizabethan poor houses, hinting at widespread abuse of the system. ${ }^{13}$ Ilana Ben-Amos argues that, by appealing to Christian charity, briefs were reminders of the breadth of 
suffering, loss, and need. ${ }^{14}$ She describes them as examples of 'public gift giving induced by the Crown'. ${ }^{15}$

This article looks at the institutional background of briefs and the changing contexts in which they operated, as well as exploring their aims, content, receptions, and limitations; it puts a particular mechanism of charity back into the context of welfare machinery. Briefs may have been the King's letters, but they arose out of demand from individuals or groups, whose needs were orchestrated by bureaucrats or (more properly) clerks, agents, or 'undertakers'. This made them a hybrid form that reflected not one, but several goals and interests. Briefs were only substitutes in a restricted sense. Instead they belonged to historically specific forms of social and political organisation. They highlight the continuing importance of voluntary giving long after compulsory rating had been established and they show how personal appeals, patronage, and impersonal agencies fitted together in a distinctively early modern way. Briefs exemplify the superimposition of national on parochial structures, 'supporting a complex matrix of resources and practices' that some might term 'welfare pluralism' ${ }^{16}$ Briefs were as much an instrument of public welfare - a concept whose connotations were for much of the early modern period 'almost boundless' as they were of charity. ${ }^{17}$ Donors' attitudes to briefs reveal regional variations in the importance to benevolence of both voluntarism and personal links, topics which have recently attracted historians' interest. ${ }^{18}$ Changing perceptions of briefs' strengths and weaknesses reflect shifts in political economy that culminated in their abolition. This article concludes by summarising continuity and change in the use of briefs over nearly three centuries, in order to remedy a concentration on the last hundred years of their existence in much of the older literature, and to highlight why both social and political historians should take them into account when studying early modern England. 
PROCEDURES, RECORDING, AND PURPOSE 1: ELIZABETHAN BRIEFS

The late-Elizabethan dockets in the Huntington Library are called 'protections to begg', guarding supplicants against being treated as vagrants under early Tudor legislation. ${ }^{19}$ That they were needed points to changes in attitudes towards poor relief in the first half of the sixteenth century. Alongside other 'technologies of identification', such as passports for vagrants being returned to their home parishes, they built on a long tradition of licensing by secular as well as religious authorities, in order to distinguish between good and bad solicitation. ${ }^{20}$ Like any national legislation or initiative, briefs supplemented local, informal efforts and there are examples of afflicted individuals and communities begging with letters substantiated by authority-figures ranging from local clergy to high-ranking nobles, but without letters patent. ${ }^{21}$ The earliest located instances of such 'passports' are from the time of Henry VII. ${ }^{22}$ Thereafter payments to poor men and women with passes can be found in churchwardens', overseers', and constables' accounts across England. Tudor JPs frequently organised collections in their jurisdictions and bishops in their dioceses, though earlyseventeenth-century legislation limited the authority of either to grant permissions for any except local gathering. ${ }^{23}$ An example of an authenticated cause without a patent, from the records of the parish of Prestbury, Cheshire, in 1672, is 'a letter of request' for Mrs Margaret Alland, 'shee being a Minister's wife, her husband troubled with the melancholy' (4s 11d collected). ${ }^{24}$

Tudor victims of misfortune could also use more formal royal letters patent and they seem to have been 'an accepted part of the English way of life before the close of Elizabeth's reign'. ${ }^{25}$ Indeed Chancery created a separate clerkship in 1567 to deal with them; Mark Steward was the first holder, then in 1586 Reginald Skryven became his partner. ${ }^{26}$ Most of the Huntington series are very short handwritten dockets on papers of various sizes, following the form of the earliest: 'A proteccon for the poore howse at Waltham crosse in the Countie of Herts graunted to Henry Allison proctor there to gather in the Counties of Midd and Surr', with the names of two or more magistrates authenticating the claim and at the bottom signed off by 'Ry: Bylford deputie to Marke Steward: esquire'. All are manuscript, costing $2 \mathrm{~s}$ per copy paid to the relevant clerk. Of the 367 awards, 252 went to individuals collecting for 'poor Houses' (hospitals and almshouses) located in or near a named place (69\%). Some 81 houses are named in the docket letters. With the exception of 
four Yorkshire houses, all lay in the south and east of England. Most received multiple licenses that either renewed the right to solicit in the same counties or added new ones; the larger hospitals near London are noteworthy (9 at Highgate, 12 at Knightsbridge, 13 at Waltham Cross, Hertfordshire) and their protections also had wider geographical range. ${ }^{27}$

The concentration on poor houses is a distinctive feature of the Elizabethan briefs, compared with later ones. Yet the Tudor briefs covered many other circumstances which were also distinctive. There were: 86 protections for 'burninge' (23\%), only 6 of them multiple; 25 for losses at sea or from robbery on land or sea, impotent war veterans, and captives who needed ransoming from 'vile slavery and miserable bondage' $(7 \%)^{28}$; only 4 protections covered the rebuilding of a church. In the case of veterans the begging brief was in lieu of a pension, provision for which had been established by an act of 1593 , always stressing service to the crown. ${ }^{29}$ A protection of August 1593 described Robert Dyer as being in extreme poverty, 'continually gravid with the Strangulation', with five 'succurless children', a veteran of wars in Ireland and the Low Countries 'and here in England in discovering of lewde and wicked persons pretending hurte against hir Matie and the realme of England' ${ }^{30}$ Standing surety (pledging) and lending money were both important parts of neighbourly duty, but both were also risky. Thus James Bennyworth had become poor 'throughe sureteishipp as also by evill debtors' ${ }^{31}$ Elizabethan protections evoke Christian charity and were meant to elicit benevolence, but within a framework better encompassed by Tudor ideas of commonwealth, whose secular component was prominent. Indeed, virtually all the Elizabethan dockets were about secular causes.

The Elizabethan series is a useful pointer to other temporal concerns, such as governance. It reflects the geography of government, mirroring other indicators such as the outreach of central courts into the provinces. ${ }^{32}$ Only one protection covered a good cause in Cheshire (at the instigation of the Council in the Marches) and one in Wales. ${ }^{33}$ Three allowed begging in Cheshire and another three in Lancashire; the four northern counties are wholly unrepresented among supplicants and only two protections let the 'proctor' and/or 'guider' solicit and collect in the eastern counties of Wales. No beneficiaries came from Derbyshire and only five patents allowed collection in the county. Yorkshire, the East Midlands and all points south are the heartland of beneficiaries and the stamping ground of proctors, including extensive coverage of the West Country. This is not to say that briefs 
were alien to the north. Churchwardens and vestry accounts for four parishes in the diocese of Durham contain dozens, but none for the period covered by the Huntington dockets; the first recorded payments, to six individuals with briefs, come from the vestry minutes of Pittington in $1619 .{ }^{34}$ This year also provides the first mention of briefs at Kirkham in Lancashire. $^{35}$ 
PROCEDURES, RECORDING, AND PURPOSE 2: HANOVERIAN BRIEFS

We must wait until the mid-eighteenth century for another near-complete collection of briefs. After 1706 returned briefs should have been deposited with the registrar of Chancery, but some briefs have found their way into private hands - perhaps via the diocesan archives to which they should have been returned, endorsed with sums collected. ${ }^{36}$ Thus we find the Crawford collection, deposited in the National Library of Scotland. It runs from 1755 to 1827, commencing the year after Thomas and John Stevenson started to 'undertake collecting of Charities by Briefs' and ending the year before briefs' abolition by Act of Parliament; it once belonged to the earl of Crawford and Balcarres, housed at Haigh Hall, Wigan, Lancashire. ${ }^{37}$ The Crawford briefs are all printed, making them technologically different from the Elizabethan collection. Printing of letters began in the time of Charles I and during his reign the Stationers' Company contested the king's grant of the monopoly to a Frenchman. ${ }^{38}$ This is also when briefs began routinely to be mentioned in State Papers, though they cease to be noted here after the Restoration. ${ }^{39}$ Printed versions became common after 1660 and compulsory from 1706 . They had to be numbered before distribution and churchwardens or clergy had to sign them and list the proceeds, also keeping a separate written record of 'occasion' or reason for the collection, its date, and amount raised - accounting for the many local tabulations. ${ }^{40}$ The undertaker's agents normally issued briefs to churchwardens at one archdeacon's visitation and collected the briefs and money at the next. They printed 10,800 copies of briefs to rebuild Anglican churches and 11,500 fire briefs, the extras to allow for settled nonconformist meeting halls. ${ }^{41}$

King's Printers like Thomas Baskett and William Strahan produced the post-1706 briefs. The papers are approximately $430 \times 270 \mathrm{~mm}$ and made to be folded twice. On the reverse of the brief the top right hand quarter asks for its return by the next visitation to the undertaker or official receiver's office in Stafford. Below this is a space for the sum collected by the persons delegated (usually the minister and churchwardens), the parish and county, and the date. Some early ones are signed off on behalf of the undertaker by John Stevenson, Queen Street, Cheapside; named collectors included John Loxdale, James Turnock, and Thomas Dudley. ${ }^{42}$ In nearly all cases in the Crawford collection, however, this part is left blank except occasionally for the collector's name, suggesting that nothing was collected by 
those given this copy or that they were not used for collecting, but kept as a record by the undertakers. One sheet has the name of the parish that received it written in this part (Widcomb St Mary Magdalen, Devon) with the addition 'no briefe ever published here', another is noted 'Hampstead Meeting', a third 'Froome' (probably Somerset), a fourth 'Harham St Marten' (Wiltshire), a fifth 'Aston Somervile' (Worcestershire). ${ }^{43}$ Opposite the 'return' section is the clause from the Act of Queen Anne prohibiting farming of briefs.

Briefs authorized collections in particular places - some in church, others door to door - in specified parts of England and Wales. The 1662 Book of Common Prayer allocated a time for reading them during divine service: 'And then also (if occasion be) shall notice be given of the Communion; and the Banns of Matrimony published; and Briefs, Citations, and Excommunications read. ${ }^{44}$ After the service the clerk was supposed to stand at the church door with a money box, and with a loud voice call out, 'Please remember the brief.' Houseto-house or 'walking' collections required churchwardens to solicit all parishioners, 'upon the Week Days next following the Publication [announcement] ... as well Masters and Mistresses, as Servants, and others in their Families, their Christian and charitable Contributions'. This would have been a considerable undertaking if conducted conscientiously and officials presumably rolled up collection with other tasks such as gathering poor rates (it would hardly seem worth asking recipients of relief). ${ }^{45}$ In the Crawford collection 23 of 623 briefs allowed collection in church, 249 house-to-house, and 351 by a combination of the two (but restricted to certain counties). House-to-house collections could only take place in those counties specified by the brief, though some writs might also allow more general soliciting throughout England, including Berwick-upon-Tweed and the counties of Flint, Denbigh, and Radnor in Wales. ${ }^{46}$ The only post-1754 household collection authorised throughout 'Great Britain' was for a church, manse, graveyard, and school to serve the Protestant enclave at Saarbruch in the Rhineland, under the protection of the prince of Nassau. ${ }^{47}$

The Hanoverian briefs differed not only in technology, but also in content and subject from their Elizabethan counterparts. Most obviously, they were about losses from natural disasters and the repair of churches, topics almost absent from the earlier collection. Briefs were meant to cope with shortfalls that individuals or communities could not make up themselves, including some truly astronomical sums. Only six of the 
Elizabethan protections state losses, these ranging from $f 100$ to $f 600$. In contrast, the Hanoverian briefs always gave a figure. Three named burgesses filed the largest English 'class action' (and the highest value at $£ 12,798$ ) on behalf of 25 Kent parishes, concerning loses caused by a hail storm on 19 August $1763 .{ }^{48}$ However, even this was topped by the whopping $£ 87,580$ ss $10 \mathrm{~d}$ requested by the 215 families from Montreal in Canada, burned out of 180 dwelling houses by a fire on 18 May $1765 .{ }^{49}$ Specifying an amount and insisting that it be verified by local builders or assessors and authenticated by the county bench may have added veracity to English and Welsh appeals, but the main point was to establish the need for a large amount, that is, more than could be raised locally. Briefs documented circumstances, but they were also fictions that drew on established reasons for claiming relief. ${ }^{50}$

One wonders what clergy, clerks, and churchwardens made of the exhortation in printed briefs to use 'all persuasive Motives and Arguments, earnestly to exhort' liberal contributions, given how hard it could be to personalize loss when the form of words varied little. Some applicants tried to make the collectors' job easier. A loser by fire in 1757 , James Rayment of Earith (Huntingdonshire), spoke the language of Christian charity when he said that his family 'who lived in Credit and Reputation before these Misfortunes happened, were always ready and willing to contribute to the Relief of others under the like Distresses' ${ }^{51}$ Sufferers from fire might write vividly of the alarming speed with which it took hold and the ferocity with which it destroyed all in its path in spite of their efforts, emoting fear to evoke pity. Those who sought funds for a church emphasised the inadequacy of their existing (strenuous and long-running) efforts and their poverty. The inhabitants of Morton in Nottinghamshire claimed they were unable to raise all the funds necessary to rebuild their dilapidated church in the 1750s, 'being chiefly Tenants at Rack Rents'; every parish claimed to be over-burdened with poor. ${ }^{52}$ Another enduring trope was loss by military action. The inhabitants of Warden in Northumberland petitioned local justices in October 1759 to certify the dilapidation of their church, 'greatly injured and ruined, in the Time of the Civil Wars formerly in this Kingdom [1640s], or by the Scots before the Union [of 1603] ${ }^{53}$

Some briefs are more specific about local conditions. Those who sought the enlargement of Lightcliffe chapel in the parish of Halifax, Yorkshire, which, 'by reason of the great Increase of Inhabitants ... will not contain One Half of the People who belong', also 
described themselves as 'Cottagers employed in the Spinning of Wool' ${ }^{54}$ In their petition of April 1758 the parishioners of Acton in Cheshire claimed to be 'burthened with numerous Poor, who are greatly increased by the Scarcity and immoderate Price of Corn' ${ }^{55}$ The church at Alston in Cumberland was ruinous and, in any case, nowhere near large enough for 'the great Increase of People on account of the Lead Mines' ${ }^{56}$

Rhetorically at least, briefs were the ultimate recourse for the needy, but where exactly they fitted into supplicants' hierarchy of resort is unclear. Some victims acted immediately and, for fire, flood, and hail damage, the median time between incident and brief in the Crawford series is four months. Sudden damage resulted in some collections for churches, but other briefs sought to remedy slow decay. The feoffees for the charities of Honiton in Devon, which had suffered from a fire in August 1768, waited more than three years before seeking a brief. The reason, as they explained, was because they had already received $£ 2,035$ from private subscriptions, of which the trustees had disbursed $£ 1,485$ to private losers. The sum of $£ 900$ requested in the brief was to add to the balance remaining and so rebuild 'publick Edifices': the church steeple and school. ${ }^{57}$ Some supplicants experienced multiple misfortunes before resorting to a king's brief. James Watkinson from Wakefield had suffered from floods in October 1767 and February 1768 and then a fire in April $1769 .^{58}$ The implication seems to be that briefs were used after other means of dealing with a loss had been exhausted.

This delay is important, because it weakens any argument that Hanoverian briefs were a substitute for insurance. During the debate on abolishing briefs in the early nineteenth century, the Home Secretary, Sir Robert Peel, suggested that 'insurance offices dispensed with the necessity of making collections in this way, in cases of loss by fire' ${ }^{59}$ Similar arguments had been offered unsuccessfully during an earlier abolition attempt in 1821. Buying building insurance did increase during the eighteenth century, but this protection was far from universal and more than two-thirds of briefs concerning London and Middlesex (including Westminster), 1656-1772, related to losses from fire. ${ }^{60}$ Only a third of all post-Restoration briefs, however, were about fires, another example where London concerns shaped national debates and legislation. At the same time most of the petitions about churches were for repairs or improvements rather than complete rebuilding following destruction, which might be considered within a policy of insurance; the churches 
described, with their bowing walls, rotten beams, subsiding foundations, and ruinous roofs would have been uninsurable. ${ }^{61}$

Briefs and insurance were functionally similar, remedying loss, but they were legally and conceptually quite different, even in the Hanoverian era. Insurance was a bilateral contract which exchanged payment for the guarantee of compensation in the event of specified future loss. Church briefs were unilateral requests for aid to cover losses already incurred, which could not be met by the petitioners and which therefore relied solely on the good will of potential donors. Insurance passed risk on to someone else in exchange for financial recompense, whereas soliciting by brief, which invited strangers to compensate for loss, simply carried a different sort of risk (that insufficient funds would be forthcoming). Supplicants had an idea of how much they needed (and probably also of their costs), but no clue about how much they would receive. Embracing uncertainty and discretion, briefs were the antithesis of insurance contracts. Briefs appealed to generalized reciprocity rather than newer, impersonal, business-modelled schemes to share risk and limit liability. ${ }^{62}$ Elizabethan briefs are even less similar to insurance in that two-thirds were appeals in anticipation of the cost of creating something new - a poor house - rather than remedying something lost.

The final factor in deciding whether to try for a brief was the need for patronage, connections, or 'interest'. Anyone could petition the crown directly, armed with certification from a local magistrate, but in the Tudor and early Stuart age the ear of a courtier was important in securing a brief. A docket from July 1593 on behalf of a lame Yorkshireman has the note: 'Comendid by Mr doctor Ambry from hir said Matie'. ${ }^{63}$ Sir John Puckering, Lord Keeper of the Great Seal (who signed all the protections in the Huntington collection) noted one for two poor houses in the city of Warwick: 'My lord doth pardon this for yt is his owne hospital'. ${ }^{64}$ Patronage remained important because of the limited number of grants, even if personal involvement by the crown, in many areas such as issuing pardons, became less normal after the Restoration, with the advent of more bureaucratic mechanisms. ${ }^{65}$ In Hanoverian times supplicants seem to have dealt directly with the undertakers in Stafford and contemporaries were aware that a disproportionate number of claims came from the Midlands (more than 70\% from within 100 miles of Stafford as the crow flies, including many from Wales); the geography is almost the opposite of Elizabethan times. ${ }^{66}$ 
Some types of collection may seem to lack any ulterior motive, a token of commitment to fellow human beings wherever they suffered; those for the benefit of coreligionists are an example. Fundraising was nevertheless also a way of showing that the person who bought the brief was politically and religiously active. Briefs allowed aspiring clergy or communities and their patrons to advertise, while feathering the nests of clerks, undertakers, and agents, who profited from the business of distributing briefs and collecting money. Hanoverian briefs exemplify a mixed economy of power and value systems as well as of welfare, blending traditional patronage, clientage, and generosity with more modern elements of bureaucracy. While there was continuity within changing administrative forms, debates about the shortcomings and usefulness of briefs, from the Restoration onwards, signposted the emergence of political rather than moral economics, which would ultimately lead to their abolition. 


\section{PROBLEMS AND ABUSES}

Throughout their history, briefs manifest the strengths and weaknesses of the different governmental forms and social norms which spawned them. Briefs may never have been popular among potential donors and a poor reputation dogged them from an early date. Understanding why helps us to explain the local responses charted in the following section as well as the reasons for the abolition of briefs in the 1820s. The nature of criticisms changed between Tudor and Hanoverian times. In the earlier period they exemplify a pervasive concern with issues of personal trust. Nobody believed honesty could be taken for granted and legislators and writers alike puzzled about how to ensure it. Elizabethan and Jacobean literature and theatre concerned themselves greatly with sincerity and transparency, both in the presentation of the self and in dealings with others. ${ }^{67}$ In the long eighteenth century commentary was more about the practical or utilitarian problems posed by briefs, as a way of collecting for good causes.

Proctors personified the perceived problems in Tudor times. John Strype's history of the Reformation lumped Elizabethan collectors with other wanderers and receivers who occupied the margins of crime: the tinker, pedlar, 'Glas-man', and 'the lewd Proctors, which carry the Broad Seal, and Green Seal, in their Baggs; cover infinite Numbers of Felonies' ${ }^{68}$ In reality embezzlement was a more likely issue. Thus in 1578 the queen required a bond of $£ 5$ from the proctor appointed to collect on behalf of the poor house at Highgate, Middlesex; he had to account for what he gathered and surrender his letter of protection to the hospital on its expiry. ${ }^{69}$ In the case of the poor house of St Anne in the parish of St Sidwells, Devon, a patent of February 1596 has a note added: 'To which poore house belongeth 3 patents which are kepte from the said house by the late Guider thereof who is removid from his rome [place] of Guidershipp'. ${ }^{70}$

Outright deception was probably rarer than collectors stretching their remit. One forgery uncovered in February 1633 borrowed the name of Viscount Wentworth to authenticate a non-existent 'great fire at Cockermouth, which took place on the 25 March 1632, and in which 105 dwelling houses were destroyed, and 41 persons were burnt to death'; the resulting scandal meant that in the following month a proclamation banned collections without express licence under the Great Seal. ${ }^{71}$ There never was a great fire at Cockermouth in 1632, but there were subtler forms of fraud. On behalf of herself and 17 
others who had been burnt out in a London fire of 1697, Margaret Mortimer alleged that the person in whose house the blaze began (Pemberton) had staved off the threat of litigation by offering to secure a brief, which 'would be a constant spring to us'. Pemberton named himself in the brief, despite allegedly being insured, along with four others who Mortimer claimed had not suffered at all in the fire. ${ }^{72}$

If Tudor and early Stuart complaints in connection with briefs were mostly about personal impropriety, later ones focused more on utility and efficiency. The Lancaster shopkeeper, William Stout, described in vivid detail how 20 houses there had been destroyed by fire in January 1698. 'The whole loss was compuited at about two thousand pounds, and a breif got, and some colectors apoynted over the nation, but the charge [of] collecting so great, that not one fourth of the value lost did not [sic] come to the sufferers. ${ }^{73}$ In January 1724 Jonathan Swift famously crossed swords with the Archbishop of Dublin over collecting on a brief for Charles M'Carthy, whose house in College-Green, Dublin, burned down in August $1723 .{ }^{74}$ Celebrated cases like this brought discussion into the public sphere and there was a steady correspondence about expenses in periodicals like the Gentleman's Magazine (1731-) throughout the eighteenth century.

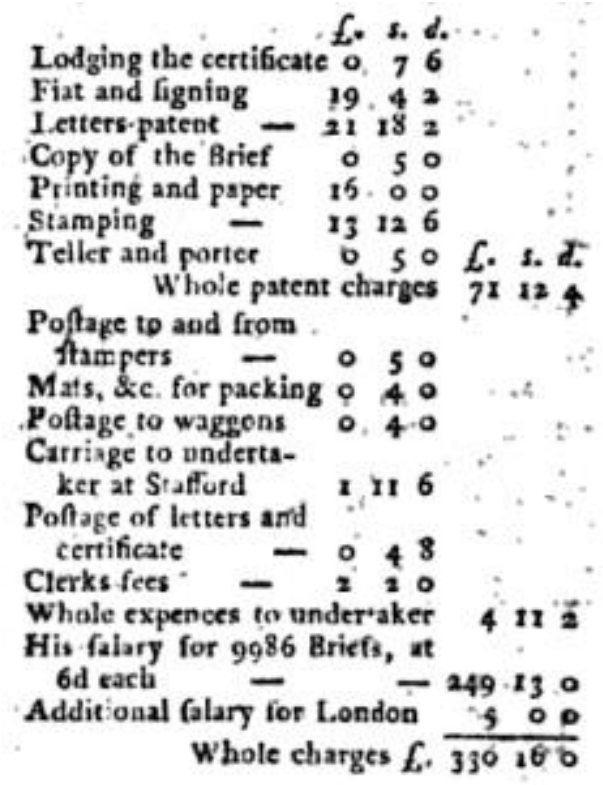

Abstract of expenses relating to the collection for Ravenstonedale, Westmorland, 1737-8, Gentleman's Magazine $(1777)^{75}$ 
The alleged frequency of briefs after the Restoration, a changed attitude towards benevolence among England's people, and new practices of government explain the legislation of 1706 that tried to deal with some of the potential for abuses and inefficiencies, including counterfeiting, farming, and high costs. ${ }^{76}$ Farming was ubiquitous in sixteenth and early seventeenth century England because the government's administrative apparatus was thin. In the case of briefs, private individuals or groups, who stood to benefit, could sell the right to receive the rewards on to someone else in exchange for a guaranteed and immediate sum. ${ }^{77}$ In Tudor and early Stuart times, owners or beneficiaries tolerated substantial losses in collecting revenue from all sorts of sources and, as a result, got low net receipts. They included the crown. For example, the costs of collecting all the income from the Duchy of Lancaster came to $60 \%$ of the gross yield. ${ }^{78}$ The crown abandoned the farming of customs in 1671 and excises in 1683 as part of the 'financial revolution' of the late seventeenth and early eighteenth century. ${ }^{79}$ Farming was inefficient and using any 'public service' in early modern England was expensive because of the need to pay the fees and grease the palms of numerous officials.

Fixed costs persuaded some petitioners to join together 'for avoiding the Trouble and Charge of separate Collections'. Indeed very few Hanoverian briefs asked for less than $£ 1,000$ - and they were all for more than $£ 900$ except a fire brief of 1771 that targeted $£ 772$ and one of 1776 that asked a mere $f 506 .{ }^{80}$ Commentators recognised the existence of this threshold thanks to costs and expectations about how much might actually be realised ${ }^{81} \mathrm{As}$ a result undertakers brought together individuals from different counties, who had common cause, to pool their claims so that the four figures could be reached. One brief of 1758 grouped losers from three separate fires in the counties of Dorset, Hertfordshire, and Huntingdonshire, which had occurred in September and December 1757 and March $1758 .{ }^{82}$ Three petitioners from Frimley (Surrey) suffered fire losses of $£ 840$ in April 1760; they appear in the same brief as two others burnt out at Bradford and Horton (both West Riding) on 20 and 31 December respectively, losing buildings and goods worth $f 285$ between them. ${ }^{83}$

It is therefore unsurprising that waste and unpopularity feature prominently in earlynineteenth-century parliamentary debates about abolishing briefs. In one, Peel flourished 
an account of briefs from the previous twelve months, choosing examples 'to show the smallness of the sum paid to the party by whom the loss had been sustained, in consequence of the immense expense incurred, for the patent, for printing notices, and for the salaries paid to officers for distributing them, and collecting the subscriptions'. More systematically, he summarized the amount lost to expenses for all the briefs issued between Michaelmas 1805 and Michaelmas 1818 (97 for repairing or rebuilding churches or chapels and 47 for accidents by fire, flood, and other disasters). With a total of $£ 125,000$ needed for the churches and $£ 36,000$ collected, the net proceeds were just over $£ 14,000$; for the accidents the figures are $£ 35,000$ and $£ 32,000$ respectively, but again the net proceeds were disappointing at under $f 15,000 .^{84}$ In theory, the brief might not attract enough contributions to cover fixed costs.

By the reign of George IV the political economy and administrative context in which briefs operated had changed out of all recognition compared with Elizabethan and early Stuart times. Public opinion had come to expect high standards of utility and propriety from the social and governmental institutions of England. Potential donors may have felt that the needy should look to their own devices, especially when they felt that they were already paying steadily rising poor rates. This was an oft-expressed opinion, but it was objectively true. Expenditure per head on poor relief increased tenfold in money terms and quadrupled in real terms between 1696 and $1803 .{ }^{85}$ The climate of opinion was changing in other respects hostile to the mixed economy of briefs. In the early nineteenth century religious reformers added to calls for abolition, on the grounds that the civil functions of the parish had unjustifiably detracted from its ecclesiastical ones. Anglican Evangelicals were keen to remove collections from the context of worship because 'it must appear, to say the least of it, very indecorous to introduce into the middle of it [divine service] a subject so totally unconnected with it'. ${ }^{86}$ 


\section{LOCAL RESPONSES: DISCRIMINATION AND 'COMPASSION FATIGUE’}

Awareness of the shortcomings of briefs and new expectations about the mechanisms and remit of public welfare bred growing scepticism and a more discriminating approach among potential donors. This reached the peak that resulted in abolition. Yet there were also enduring regional variations in attitudes towards giving, and to the level of trust that could be placed in what briefs claimed. The main division was between the societies of north and west England and Wales on the one hand, and the south and east on the other. The varying reception of briefs points to divergences in the social priorities of people in different regions of Britain. This section concludes by looking at the number of collections over time and the problem of 'compassion fatigue'.

Taking the case of the north first of all, diaries and account books help us to understand how potential donors reacted to briefs. The Catholic gentleman, Nicholas Blundell of Little Crosby (Lancashire), recorded how on 29 December 1702 'Church Wardens came abegging with two Breefs'; he describes other briefs in a similar way though he did sometimes donate, including once to 'a poore Man with a Breef' who appeared in person on 3 February $1710 .^{87} \mathrm{He}$ also enquired closely into some claims, recording in detail the following occasion. His vicar and two churchwardens 'were here abeging upon Account of the Great Losses sustained in Lancashire in December ... 1720 by the Violent overflowing of the Sea'. The vicar had shown him the brief, but he sought out a copy for himself, noting 6600 acres inundated, destroying 157 Houses and damaging 200 more, 'the whole loss was Computed to be more than $\mathrm{f} 10277$. I Suppose this Account may be pretty exact for I heard some Persons examined upon Oath concerning some part hereof and they swore pretty near what I had heard from other Persons. ${ }^{88}$ This was a county matter and Blundell gave five shillings, the largest sum he records in response to any brief.

Others were equally careful about claims and especially cautious about giving to strangers. Sir Daniel Fleming of Rydal, a prominent landowner and public figure in lateseventeenth-century Westmorland, accounted for just eleven contributions to briefs in his detailed household books, 1688-1701, giving to less than one in ten of all the briefs that circulated during this period. ${ }^{89}$ Over a 20 year period (1758-78) the Cumberland Quaker, Isaac Fletcher, accounted for 31 named briefs on 13 occasions; most collections are recorded in batches of between two and five at a time, proceeds handed over to agents or 
collectors whenever a visitation occurred or when the responsible person visited a town. ${ }^{90}$ On 27 April 1761 Fletcher recorded how he was 'At the Commissary Court: got Mary Head's will proved. Paid J. Collison the brief money which I collected yesterday: 6s 4d. Richard Warren [the collector] was not there' ${ }^{91}$ Eighteen months later 'At the Commissary Court paid James Collinson [sic], collector, the brief money ... \& returned the church brief' ${ }^{92}$ Perhaps reflecting the seasonality of loss from hail or fire, most of those Fletcher mentions came in at, or just after, harvest time - 8 of the 13 are in September or October - also the time when rural people felt most prosperous and generous. ${ }^{93}$ The median sum collected was $2 \mathrm{~s} 6 \mathrm{~d}$ per brief.

Collectors commented on the uphill task of soliciting, especially in some regions, or in periods of dearth, or when there were more briefs than usual. One, appointed to collect in Yorkshire for the town of Beccles in Suffolk (devastated by fire in 1586), said in 1591 that he had spent more than a year touring around, meeting with little response. ${ }^{94}$ To cope with reluctance to give to strangers, some communities levied a fixed (if token) contribution or they did not collect expressly for the brief, but donated from cash-in-hand. ${ }^{95}$ The sworn men of Kirkham in Lancashire told the churchwardens in September 1690 that no brief from king or bishop should receive less than 5 s from the parish; if the loss was over $£ 1000$ the minimum became $6 \mathrm{~s} 8 \mathrm{~d}$ and above $f 5000$ it was $f 1 .{ }^{96}$ Elsewhere in the north (where select vestries were common from an early date), church briefs also appear on the expenditure side of parish accounts, vestries disbursing from general funds as they saw fit rather than soliciting specifically. ${ }^{97}$ The West Country may have had attitudes comparable with the north because a high proportion of briefs there collected nothing at all: 403 of 1,103 at East Budleigh, Devon, $1669-1828$ (37\%) and a further 549 collected brought in just $1 / 4 \mathrm{~d}-1 \mathrm{~s}(50 \%) .{ }^{98}$

These examples are from the north and north-west of England, but the Welsh too seem to have been discriminating about giving for briefs. William Bulkeley recorded, in his diary for 24 May 1741, that he contributed to a bed-ridden woman from a nearby parish on Anglesey whom he thought deserving; the Welsh called these local collections cymorthau to distinguish them from church briefs (lythyrau casgl). ${ }^{99}$ Bulkeley added, in a critical tone that conveyed the need for personal knowledge or reliable endorsement: 'as for others recommended by the Ministers from places remote [on briefs], as he never mentions the names of creditable neighbours to vouch for their condition, those may, or may not be, 
objects of charity'. ${ }^{100}$ The Welsh in particular may always have been reluctant to help those not vouched for or immediately visible to them. In response to an appeal to aid Genevan Protestants during Elizabeth's reign, the bishop of St David's wrote, 'I have dealt with some of the best of my diocese, who I find not greatly willing because it is in another country. And as for my clergy they all allege poverty. ${ }^{, 101}$

The bishop must have found the attitude of his ministry particularly galling. Clergy were supposed to set an example for both charity and benevolence. Following Matthew 6:3, George Herbert's popular prototype of 'the country parson, his character, and rule of life', $\underline{A}$ priest to the temple, included the suggestion that any vicar worth his salt would not wait for a brief to be issued, but would himself give spontaneously and liberally as soon as he knew of a good cause - and then urge others to do the same. ${ }^{102}$ Secular authorities thought the problem lay more with what the bishop called 'the best' (élites). In July 1637 the Privy Council wrote to the Lord President and Council in the Marches of Wales complaining of the 'slowe \& meane' response to the king's brief for the repair of St Paul's Cathedral in London. The Lords thought an important reason was that 'many of knowne abilities have refused or very meanely contributed, geuing example thereby to the inferior sorts to hold their way'. ${ }^{103}$ This does not mean that the Welsh or northeners were uncaring or too impoverished to give; they simply needed to feel direct affinity with the objects of their benevolence. The geography of Hanoverian briefs, which we noted earlier, may be explained by the continued adherence to voluntarism in the north and west of England and in Wales. These were, after all, the areas that saw the most vocal opposition to the Poor Law Amendment Act of 1834, condemned at Bury (Lancashire) as 'an instrument of ... cruel outrages'. ${ }^{104}$

Churchwardens or chapel-wardens might need the additional authority of the vicar 'or some of the substantial Inhabitants', when going house-to-house in other parts of England. The Sussex shopkeeper Thomas Turner accompanied the rector of East Hoathly when he went through his parish in March 1765, collecting for the victims of a hailstorm of August 1763. The process took two days as not everyone was at home when first called upon, but in the end Turner was able to list 57 donors (including himself) who gave sums ranging from $5 \mathrm{~s}$ (the vicar) to a handful who gave only $1 \mathrm{~d}$ (total $f 112 \mathrm{~s} 0 \mathrm{~d}$ ). ${ }^{105}$ This procedure was feasible in a small southern English parish like Turner's (numbering about 350 souls), but unworkable in the sometimes vast parishes of the north of England or 
Wales. ${ }^{106}$ This was truly door-to-door collecting, following the spirit and letter of briefs. With more than a century of regular rating behind them, parishes like this may have treated briefs in the same way as statutory taxation for the poor, whereas extensive rating may not have been so familiar to the peoples of the north and west before the eighteenth century. Yet even in the English heartland some must have baulked at promoting causes of which they were either ignorant or actively suspicious.

The frequency of briefs attracted as much comment after the Restoration as did their seeming irrelevance to local circumstances. In his diary for 30 June 1661 Samuel Pepys famously wrote: 'To church, where we observe the trade of briefs is come now up to so constant a course every Sunday, that we resolve to give no more to them.' The collection that provoked his outburst was 'for several inhabitants of the parish of St Dunstan in the West towards their losse by fire' (20s. 8d. collected) and briefs had indeed been promoted in St Olave, Hart Street, Pepys's parish church, 14 weeks successively previous to this; Bewes reports 'about 51' for the year 1661-2. ${ }^{107}$ The inundation seems to have been a response to pent up demand for royal patronage during the Interregnum. The post-Restoration times were exceptional, but the crown and its agents had long been aware of the need to be selective and to space permissions if possible. In 1633, when briefs were much in the public eye, the Lord Keeper suggested refusing a collection for Protestant sufferers at the hands of the Catholic army plundering Magdeburg in Saxony, because there had been so many such petitions. ${ }^{108}$ Grants were not always so discriminating. The victims of fire at Church Stretton, Shropshire, renewed their brief because the 'former grant was no benefytt to the said Inhabitannts by reason that there was a late gathering in every of the last named Counties [Cheshire, Herefordshire, Worcestershire, and Gloucestershire] ... [for] Marlboroughe and Stratforde'. ${ }^{109}$

The impression that briefs were too common must have been augmented on occasions when vicars read out more than one at service. James Clegg, a Derbyshire dissenting minister, recorded in his diary that, on 30 September 1733, he 'catechizd only once because we had briefes to read'; on 9 June 1734 he read two briefs. ${ }^{110}$ These examples must represent local circumstances (such as clerical illness or absence) that caused clustering because Bewes reports that seldom more than 20 a year can be found in central archives from 1642 onwards and that the average was one a month. The Crawford briefs 
average just under nine per year. For the same period as the Crawford collection John Stevenson Salt, the last official 'undertaker' of briefs at the time of their abolition in 1828, gave to the British Library a collection of manuscript letters patent, that may include all briefs issued 1755-1827; these number 663 or just over nine a year on average. ${ }^{111}$

Seen from the bottom up a similar figure emerges. Paul Slack shows that one London parish registered 471 briefs between 1581 and $1620 .{ }^{112}$ Clocaenog in the Vale of Clwyd kept a careful record of briefs from soon after the act reforming them in 1706, recording 172 between 1709 and $1736 .{ }^{113}$ The parish registers of Dalston in Cumberland record dozens of king's briefs in the late seventeenth century and fully 173 during the two decades after 1805 , though this still amounts to less than one a month. ${ }^{114}$ A carefully kept local tally of briefs, for the Devon parish of East Budleigh, 1669-1828, is the longest known and boasts 1,035 entries. It has 114 fewer briefs for the period covered by the Crawford collection. Some may not have applied to Devon and there seem to be missing years in this series, giving a lower average of between six and seven per year. ${ }^{115}$ The contrast with the frequency of Elizabethan protections is clear. During the 1590s they were more than three times as numerous, though admittedly covering smaller areas. Except for occasional logjams, increasing criticism of briefs from the Restoration must have been the result of a changing threshold of tolerance among donors, rather than of the objective incidence of requests.

The remoteness of their cause, their perceived frequency, and a changed climate of opinion in which donors were constantly aware of compulsory rating explains mounting criticism. Swift summed up a prominent strand in 1724.

The collections upon the Lord's day are the principal support of our own numerous poor in our several parishes; and therefore every single brief, with the benefit of a full collection over the whole kingdom, must deprive several thousands of poor of their weekly maintenance, for the sake only of one person, who often becomes a sufferer by his own folly or negligence, and is sure to overvalue his losses double or treble ... and thus, for the advantage of ... persons, whereof not one in ten is deserving, and for the interest of a dozen dexterous clerks and secretaries, the whole poor in the kingdom will be likely to starve. ${ }^{116}$ 
Swift had earlier satirised meanness in 'Memoirs of P. P., Clerk to this Parish' (c.1705), where he suggested that nine collections for as many churches raised just $2 \mathrm{~s} .73 / 4 \mathrm{~d}$ and one for 50 families ruined by fire a paltry 1s. $1 / 2$ d. ${ }^{117}$ Certain appeals did attract large sums of money, notably for beleaguered Protestants abroad, but these made up only a small proportion of all causes and it is hard to escape the conclusion that the sanction of the crown was necessary to galvanize reluctant givers into taking account of worthy causes beyond those with which they were intimately associated. Ben-Amos suggests that briefs transcended locality, but the sense is that monarchs (and anyone involved in promoting such collections, including bishops and their clergy) had increasingly to goad parishioners into giving. ${ }^{118}$ Briefs might be relatively infrequent, but they were still regular and 'compassion fatigue' must have been considerable. The short length of time between issuing and registration of return among the Crawford collection suggests either that pleas were made only once or, at most, that the 'half-life' of briefs was measured in days, another important contrast with the Elizabethan licenses, which lasted a full year (they were so because proctors went in person around all the parishes in the authorised counties). More similarities and differences over time are discussed in the concluding section. 


\section{CONTINUITY AND CHANGE}

On the surface, the briefs of the early nineteenth century were the same as those of the late sixteenth: letters patent which still used the same sort of language. A rare request of May 1593 for funds to rebuild a parish church at Dodington (Northamptonshire) rehearsed how it had been derelict for half a century, the inhabitants unable to 'reedifie' it without outside help, hard as they had tried; the narrative would have been recognisable two centuries later. ${ }^{119}$ Criticisms of abuses found in Tudor times never went away, in spite of attempts at reform under the later Stuarts. Briefs still required patronage and connections, even within increasingly bureaucratised governmental forms. Hanoverian briefs continued to pursue the ends of public welfare and merely indigent individuals were few. People who applied tended to be the owners of large enterprises such as mills or warehouses, which not only had a substantial value for buildings and stock, but also were significant to local economies. ${ }^{120}$ More broadly, it is surprising how long an Aristotelian vision of commonwealth lasted, focusing on the promotion of informed transaction and on the virtues of voluntarism, while accepting the need on occasion for an externally imposed stimulus like a brief. ${ }^{121}$ The role in this of institutional inertia or vested interest may repay further study.

The purposes of briefs nevertheless changed over time and so did the context of their collection. After Elizabeth's reign petitioners seldom used briefs for routine funding of poor houses, even after enabling legislation of $1696 .{ }^{122}$ The crucial change came after the late-Elizabethan poor laws since, when runs of briefs become available in individual parish records after the mid-seventeenth century, they show that churches had taken the place of poor houses as the objects of building requests; in this regard, Hanoverian briefs were less secular than Elizabethan ones. Losses from non-natural causes almost disappeared after the mid-seventeenth century. ${ }^{123}$ For example, sureties and bad debtors were absent because there were newer, simpler, and more effective legal means of dealing with debt, most notably by writ of assumpsit. ${ }^{124}$ Nor were there any longer collections made on behalf of those who had become aged and infirm in the service of the crown, despite the massive increase in military participation rates during the 'second Hundred Years War'. ${ }^{125}$ The place of begging in the hierarchy of resort became more clearly defined - and less important - as a result of late-sixteenth- and seventeenth-century developments in the law and practice of 
poor relief. Thus Hanoverian briefs on behalf of groups or communities looked for help mainly in the building or repair of churches. The eighteenth century saw the emergence of a more obvious connection between charity and the institutions of religion, rather than the universal spirit of Christian charity, commonwealth, and the all-encompassing conception of welfare that had informed pre-Civil War royal letters.

Indeed Hanoverian briefs were not simply a survival of older charitable traditions. In some senses they carried on the function of church ales, which in their pre-Edwardian heyday were for church projects rather than poor relief. ${ }^{126}$ It is, however, clear that until the mid-seventeenth century briefs were little used for church building or repair; they more closely resembled help-ales. ${ }^{127}$ Four crucial differences remained. First, help-ales raised small sums (a few pounds each at most) where briefs covered substantial losses; it would have taken dozens of drinkings to raise the sums envisaged in the protections of the 1590s, let alone the sometimes enormous targets of the Hanoverian briefs. ${ }^{128}$ Second, briefs promised a lump sum within weeks or months whereas, for example, it took Ashburton in Devon the period between 1485 and 1530 to raise $£ 315$ by ales. ${ }^{129}$ In 1600 Tewkesbury in Gloucestershire netted $£ 45$, two-thirds of the cost of rebuilding part of the church, but this marks the limits of what could be achieved by ales. ${ }^{130}$ Third, briefs authorized appeals for distant causes, even when a beneficiary or proctor personalised the request, whereas church and bid ales raised funds for people or objects close to contributors. Fourth, ales had a social side, whereas briefs were clinically financial. We might note in passing that it is impracticable to calculate the relative significance of briefs to overall expenditure on the poor, except at parish level. In Elizabethan St Botolph Aldgate, London, for example, authorized collections realized $£ 8$ per year, compared with $£ 40$ from poor rates. ${ }^{131}$ Casual giving and other help cannot be documented systematically and the best that can be said is that briefs had a supplementary, if opaque, relationship with other parts of 'the mixed economy of welfare'.

As well as making different types of request, Hanoverian briefs were contextually different from their Elizabethan forerunners. Later church or parish officials organised collections in church or at houses, whereas Tudor beneficiaries or their proctors also solicited in person wherever they could. At the same time, early proctors were responsible for transmitting net proceeds to the poor house or other good cause, whereas later briefs 
had set bureaucratic channels. ${ }^{132}$ Hanoverian benevolence took on and projected a new set of meanings, including sentiment and sensibility, linking charity, religion, fashion, and politics. ${ }^{133}$ Geographical breadth changed too. The norm in Elizabethan times was to sanction collection in just two shires, adjacent or close to their good cause. No brief was national and, except for one covering the province of Canterbury (and for the unusual span of three years), the most geographically extensive covered six counties. ${ }^{134}$ The Hanoverian briefs encompassed a larger area and many more were national. They were geographically broad requests, similar in kind to those handled by the post-Restoration English royal almoner; they were about fellow Christians, but usually complete strangers. Expensive and cumbersome to obtain, they were mostly for causes that had no local resonance and indeed some parishes and peoples resented them for draining resources from their own immediate needs, whether buildings, furnishings, or the poor. ${ }^{135}$

Finally, we might reflect on the afterlife of briefs, because raising money through crown patronage did not end in 1828. 'King's Letters', which Peel proposed as a replacement for briefs, survived into the mid-Victorian period; documents of a similar character were granted to the Incorporated Societies for Church Building, Missions, and Education. ${ }^{136}$ In their final years these letters returned to the purposes of social improvement shown by their Elizabethan counterparts, though manifesting, in a quite different political and administrative context, a more narrowly defined vision of welfare than the 'almost boundless' one of Tudor and early Stuart days. 
ENDNOTES

${ }^{1}$ I am grateful to Steve Hindle, Jo Innes, Marjorie McIntosh, and Paul Slack for comments on an earlier draft.

${ }^{2}$ The literature is vast, but the following represent some of the best recent work. Paul Slack, Poverty and Policy in Tudor and Stuart England (London: Longman, 1988). Steve Hindle, On the Parish. The Micro-Politics of Poor Relief in Rural England, 1550-1750 (Oxford: Oxford University Press, 2004). Ilana K. Ben-Amos, The Culture of Giving: Informal Support and GiftExchange in Early Modern England (Cambridge: Cambridge University Press, 2008). Marjorie K. McIntosh, Poor Relief in England, 1350-1600 (Cambridge: Cambridge University Press, 2012).

${ }^{3}$ Letters patent authorizing collections for good causes nevertheless preceded the Reformation. For one printed example from 1515 (to relieve prisoners of Barbary pirates) see H. Ellis, Original Letters, Illustrative of English History Second Series, 4 vols (London: British Museum, 1827), vol. 1, 268-71. Ellis's gloss to the document notes examples from the reigns of Edward IV and Richard III.

${ }^{4}$ McIntosh, Poor Relief, 45-52.

${ }^{5}$ For example, Rev. Thomas Walker, M.A., vicar of Clent (formerly Staffordshire) kept a notebook of collections on Briefs 1672-1718. Notes \& Queries 5th series 4, 447-81, abstracted in Cornelius Walford, 'Kings' Briefs: their Purposes and History', Transactions of the Royal Historical Society 10 (1882), 61-8.

${ }^{6}$ Wyndham A. Bewes, Church Briefs, or Royal Warrants for Collections for Charitable Objects (London: Adam and Charles Black, 1896).

${ }^{7}$ Walford, 'Kings' Briefs', 1-74. Quotation from Oxford Dictionary of National Biography:

'Walford, Cornelius (1827-1885)'.

${ }^{8}$ Walford, 'Kings' Briefs', 2.

${ }^{9}$ William G. D. Fletcher, 'Leicestershire Church Briefs', Transactions of the Leicestershire Architectural and Archaeological Society 8 (1898), 387-90. C. Maddock, 'Records of the 
Church Briefs Published and Collected in South Holderness Parishes', The Transactions of the East Riding Antiquarian Society 7 (1899), 84-99. C. W. Shickle, 'Keynsham Briefs', Proceedings of the Bath Natural History and Antiquarian Field Club 9 (1901), 110-25. Joel Cadbury, 'King's Briefs the Forerunners of Mutual Insurance Societies', Journal of Friends' Historical Society 3 (1906), 106-12. Lilian G. Ping, ‘Raising Funds for “Good Causes” During the Reformation', Hibbert Journal 35 (1936-7), 53-66. Maurice H. Ridgway, Briefs and Collections in Bunbury Church, Cheshire, 1665-1704. Part 1 (Nantwich: np, 1949). Gwynfryn Richards, 'King's Briefs and Begging Letters', Cymdeithas Ceredigion Llundain [The Cardigan Society of London] 10 (1954-5), 11-16. C. J. Kitching, 'Fire Disasters and Fire Relief in Sixteenth-Century England: the Nantwich Fire of 1583', Bulletin of the Institute of Historical Research 54 (1981), 171-87. F. Sharman, 'Fires and Fire Laws up to the Middle of the Eighteenth Century', Cambrian Law Review 22 (1991), 42-54.

${ }^{10}$ Joan Beck, 'A Study of the Causes, Administration and Results of Lancashire Church Briefs, and Studies of Collections for Lancashire and non-Lancashire Briefs, with Reference to Collections Elsewhere in England' (MA Thesis: University of London, 1954), a summary of which appeared in Amateur Historian 2 (1954-56), 165-167. Thomas L. Auffenberg, 'Organized English Benevolence: Charity Briefs, 1625-1705' (Ph.D. Thesis: Vanderbilt University, 1973); 'Church-State Philanthropy: English Charity Briefs and the Relief of Persecuted Continental Protestants', Journal of Church \& State 21 (1979), 287-303. D. Kenyon, 'Faith, Hope or Charity?: Church Briefs Recorded in South Derbyshire Parishes 16581735’ (M.A. Thesis: University of Nottingham, 1990). S. Nishikawa, 'English Attitudes toward Continental Protestants with Particular Reference to Church Briefs c. 1680-1730s' (Ph.D. Thesis: University of London, 1998). Mark Harris, 'Inky Blots and Rotten Parchment Bonds: London, Charity Briefs and the Guildhall Library', Historical Research 66 (1993), 98-110; 'The Finding and Use of Brief Records', Archives 21 (1994), 129-44.

${ }^{11}$ E. M. Leonard, The Early History of English Poor Relief (Cambridge: Cambridge University Press, 1900), 203.

${ }^{12}$ Hindle, On the Parish, 59.

${ }^{13}$ McIntosh, Poor Relief, 162-4, 172-85, 279.

${ }^{14}$ Ben-Amos, Culture of Giving, 337-40. 
15 Ibid. 338.

${ }^{16}$ Joanna Innes, "The "Mixed Economy of Welfare" in Early Modern England: Assessments of the Options from Hale to Malthus (c.1683-1803), in Martin Daunton ed., Charity, SelfInterest and Welfare in the English Past (London: UCL Press, 1996), 143. F. J. Gladstone, Voluntary Action in a Changing World (London: National Council of Social Service, 1979), 100.

${ }^{17}$ Paul Slack, From Reformation to Improvement: Public Welfare in Early Modern England (Oxford: Oxford University Press, 1999), 1.

${ }^{18}$ R. A. Houston, Bride Ales and Penny Weddings: Recreations, Reciprocity, and Regions in Britain from the Sixteenth to the Nineteenth Century (Oxford: Oxford University Press, 2014), 187-92.

${ }^{19}$ Kitching, 'Fire Disasters', 175-6. Ben-Amos, Culture of Giving, 86-7.

${ }^{20}$ Steve Hindle, 'Technologies of Identification under the Old Poor Law', Local Historian 36 (2006), 220-36. R. A. Houston, 'Vagrants and Society in Early Modern England', Cambridge Anthropology (1980), 18-32.

${ }^{21}$ Ian Archer, 'The Charity of Early Modern Londoners', Transactions of the Royal Historical Society 12 (2002), 239. Ben-Amos, Culture of Giving, 90, 92, 94.

22 John A. F. Thomson, The Early Tudor Church and Society, 1485-1529 (London: Longman, 1993), 334. Authenticated petitions for Relief from the private victims of misfortune were still being printed into the 1850s. John Ballinger, 'Local History from a Printer's File', in Francis Green ed., West Wales historical records vol. X (Carmarthen: W. Spurrell and Son, 1925), 171-4.

${ }^{23}$ Kitching, 'Fire Disasters', 174.

${ }^{24}$ Frank Renaud ed., Contributions towards a History of the Ancient Parish of Prestbury, in Cheshire (Manchester: Chetham Society, 1876), 53.

${ }^{25}$ Kitching, 'Fire Disasters', 176.

${ }^{26}$ Huntington Library (HL) Ellesmere 1345, 1346. 
${ }^{27}$ HL Ellesmere 3044-5609 (not all of this range comprises dockets for this purpose); quotations from 3044. Mclntosh, Poor Relief, 163-4.

${ }^{28}$ HL Ellesmere 3432. Roslyn L. Knutson, 'Elizabethan Documents, Captivity Narratives, and the Market for Foreign History Plays', English Literary Renaissance 26 (1996), 75-110. Maritime insurance existed in Elizabethan times. David Ibbetson, 'Law and Custom: Insurance in Sixteenth-Century England', Journal of Legal History 29 (2008), 291-307. ${ }^{29}$ Geoffrey L. Hudson, 'Arguing Disability: Ex-Servicemen's Own Stories in Early Modern England, 1590-1790', in Roberta Bivins and John V. Pickstone eds., Medicine, Madness and Social History: Essays in Honour of Roy Porter (Basingstoke: Palgrave, 2007), 105-17. HL Ellesmere 5202.

${ }^{30} \mathrm{HL}$ Ellesmere 3514. Protestant refugees from Ireland were legitimate beneficiaries of briefs. John McGurk, 'The Dead, Sick and Wounded of the Nine Years War, 1594-1603', History Ireland 3, 4 (July 1995), 16-22. McIntosh, Poor Relief, 156-8. Under the Protectorate royal briefs first extended to Ireland, which had acquired other aspects of English charitable practices (like a royal almoner) only in the early Stuart period, and which arguably did not have a functioning poor law until 1838. HL Ellesmere 4200. A Distinct and Faithful Accompt of All the Receipts, Disbursements, and Remainder of the Moneys Collected in England, Wales \& Ireland, for the Relief of the Poor Distressed Protestants in the Valleys of Piemont (London: Hen. Hills and John Field, 1658). R. A. Houston, 'What did the Royal Almoner do in Britain and Ireland, c.1450-1700?', English Historical Review cxxv, 513 (April 2010), 27-8.

${ }^{31}$ HL Ellesmere 3475. Martin Pimsler, 'Solidarity in the Medieval Village? The Evidence of Personal Pledging at Elton, Huntingdonshire', Journal of British Studies 17 (1977), 1-11. For a testimonial issued by the mayor and sheriffs of York in 1502, to support begging by a glover who had gone mad after the default of those for whom he pledged, see Thomson, Early Tudor Church, 334.

${ }^{32}$ Richard W. Hoyle and Henry R. Summerson, 'Handlist of Star Chamber Pleadings before 1558 for Northern England', List and Index Society 299 (Kew: The National Archives, 2003).

${ }^{33}$ HL Ellesmere 4996, 5360. 
${ }^{34}$ James Barmby ed., Churchwardens Accounts of Pittington and Other Parishes in the Diocese of Durham from A. D. 1580 to 1700 (Durham: Surtees Society, 1888), 76-7.

${ }^{35}$ R. Cunliffe Shaw and Helen G. Shaw eds., The Records of the Thirty Men of the Parish of Kirkham in Lancashire (Kendal: T. Wilson, 1930), 18.

36 'An Act for the Better Collecting Charity Money on Briefs by Letters Patents, and Preventing Abuses in Relation to Such Charities', 4 \& 5 Anne, c. 14. Walford, 'Kings' Briefs', 4.

${ }^{37}$ NLS Crawford CB, boxes 1-6. Bewes, Church Briefs, 50.

${ }^{38}$ A member of the company had received the grant in 1587. Henry Church Maxwell Lyte, Historical Notes on the Use of the Great Seal of England (London: HMSO, 1926), 278.

${ }^{39}$ For mentions in State Papers see, for example, John Bruce ed., Calendar of the State Papers, Domestic Series ... 1625, 1626 (London: Public Record Office, 1858), 83, 155, 342, $434,526,557$.

${ }^{40}$ Walford, 'Kings' Briefs', 25. Bewes, Church Briefs, 394-9.

${ }^{41}$ Vanessa S. Doe ed., The Diary of James Clegg of Chapel en le Frith, 1708-1755 3 vols consecutively paginated (Matlock: Derbyshire Record Society, 1978-81), 278. Angus J. L. Winchester ed., The Diary of Isaac Fletcher of Underwood, Cumberland, 1756-1781 (Kendal: Cumberland and Westmorland Antiquarian and Archaeological Society, 1994), index. There is no way of telling how they arrived at this figure.

${ }^{42}$ Bewes, Church Briefs, 54-5.

${ }^{43}$ NLS Crawford CB.78, 98, 109, 138, 160.

${ }^{44}$ The act of 1706 specified reading before the Sunday sermon.

${ }^{45}$ NLS Crawford CB.2. T. N. Brushfield, 'Devonshire Briefs Part II', Report and Transactions of the Devonshire Association for the Advancement of Science, Literature and Art 28 (1896), 612.

${ }^{46}$ North Wales was the poorest part of the principality, but Bewes, Church Briefs, 49 , states that collections elsewhere in Wales were also 'unremunerative'. 
${ }^{47}$ NLS Crawford CB.54.

${ }^{48}$ NLS Crawford CB.77.

${ }^{49}$ Cumberland Quakers immediately collected $\mathrm{f} 1$ 4s $4 \mathrm{~d}$ for the victims. Winchester ed., Diary of Isaac Fletcher, 200.

${ }^{50}$ Cf. the petitions analysed in Hindle, On the Parish, 156-63, 407-28.

${ }^{51}$ NLS Crawford CB.17.

${ }^{52}$ NLS Crawford CB.3.

${ }^{53}$ NLS Crawford CB.43. Hindle, On the Parish, 158.

${ }^{54}$ NLS Crawford CB.7.

${ }^{55}$ NLS Crawford CB.22.

${ }^{56}$ NLS Crawford CB.85.

${ }^{57}$ National Library of Scotland (NLS) Crawford CB.123. Trustees are named, conventionally the relevant bishop and his clerks, lord-lieutenant, the county bench, and the minister and churchwardens of the parish or chapelry in the case of a request to fund the rebuilding, repairing, or enlarging of a church.

${ }^{58}$ NLS Crawford CB.134.

${ }^{59}$ HC Debates 22 May 1828, vol. 19, 872.

${ }^{60}$ Harris, 'London, Charity Briefs', 102.

${ }^{61}$ There were other means of raising funds, such as local legislation. Basil F. L. Clarke, The Building of the Eighteenth-Century Church (London: S.P.C.K., 1963), 46-112.

${ }^{62}$ Geoffrey Clark, Betting on Lives: the Culture of Life Insurance in England, 1695-1775 (Manchester: Manchester University Press, 1999).

${ }^{63}$ HL Ellesmere 3478.

${ }^{64}$ HL Ellesmere 3754.

${ }^{65}$ Paul Carter, 'Early Nineteenth-Century Criminal Petitions: an Introduction for Local Historians', Local Historian 31, 3 (2001), 147. 
${ }^{66}$ Gentleman's Magazine 77 (1807), 228.

${ }^{67}$ Perez Zagorin, Ways of Lying: Dissimulation, Persecution and Conformity in Early Modern Europe (Cambridge, Mass.: Harvard University Press, 1990).

68 J. Strype, Annals of the Reformation and Establishment of Religion, in the Church of England 4 vols (London: Edward Symon, 1735-8), vol. 4, 293.

${ }^{69}$ McIntosh, Poor Relief, 163. Highgate was still collecting two decades later. HL Ellesmere 5405,5413 , both from January 1596 are only the last recorded in a series of protections issued.

${ }^{70}$ HL Ellesmere 5480.

${ }^{71}$ C.S.P. Domestic 1631-1633, 546, 580. For another fraud see Claire S. Schen, 'Constructing the Poor in Early Seventeenth-Century London', Albion 32 (2000), 455. McIntosh, Poor Relief, 173-85, deals extensively with the issue.

72 Walford, 'Kings' Briefs', 31.

73 John D. Marshall ed., The Autobiography of William Stout of Lancaster, 1665-1752 (Manchester: Chetham Society, 1967), 120.

${ }^{74}$ The Works of the Rev. Dr. Jonathan Swift, Dean of St. Patrick's, Dublin. Arranged, Revised, and Corrected, with Notes, by Thomas Sheridan, A.M. 17 vols (London: W. Straham et al, 1784), vol. 16, 301-9. The beneficiary allegedly started the fire himself. R. Dudley, 'The Dublin Parishes and the Poor, 1660-1740', Archivium Hibernicum: Irish Historical Records 53 (1999), 85.

${ }^{75}$ Bewes, Church Briefs, 36-7.

${ }^{76}$ For an earlier example of a suspected forgery see C.S.P. Domestic 1625, 1626, 342, 343.

77 Bewes, Church Briefs, 32-3.

${ }^{78}$ Richard W. Hoyle, 'Introduction: Aspects of the Crown's Estate, c.1558-1640', in Richard W. Hoyle ed., The Estates of the English Crown, 1558-1640 (Cambridge: Cambridge University Press, 1992), 34. 
79 Patrick K. O'Brien and Philip A. Hunt, 'England, 1485-1815', in R. Bonney ed., The Rise of the Fiscal State in Europe, c.1200-1815 (Oxford: Oxford University Press, 1999), 73.

${ }^{80}$ NLS Crawford CB.105, 123, 134, 148, 192.

${ }^{81}$ Bewes, Church Briefs, 39.

${ }^{82}$ NLS Crawford CB.17.

${ }^{83}$ NLS Crawford CB.45.

${ }^{84}$ John Henry Blunt ed., The Annotated Book of Common Prayer 2 parts (London:

Rivingtons, 1866), part 2, 171n. Some earlier briefs had much lower expenses, though still of the order of 25\%. Walford, 'Kings' Briefs', 42-3.

85 P. Slack, The English Poor Law, 1531-1782 (Basingstoke: Macmillan, 1990), 30, 34.

${ }^{86}$ HC Debates 22 May 1828, vol. 19, 872.

87 J. J. Bagley ed., The Great Diurnal of Nicholas Blundell of Little Crosby, Lancashire. Volume 1, 1702-1711 (Chester: Record Society of Lancashire and Cheshire, 1968), 26, 108, 147, 232, 244; The Great Diurnal of Nicholas Blundell of Little Crosby, Lancashire. Volume 2, 17121719 (Chester: Record Society of Lancashire and Cheshire, 1970), 3, 40, 93, 150. He noted in particular collections for losses from cattle murrain (probably foot and mouth disease) in 1714 and 1715. Ibid., 120, 150.

${ }^{88}$ J. J. Bagley ed., The Great Diurnal of Nicholas Blundell of Little Crosby, Lancashire. Volume 3, 1720-1728 (Chester: Record Society of Lancashire and Cheshire, 1972), 79.

${ }^{89}$ Blake Tyson ed., The Estate and Household Accounts of Sir Daniel Fleming of Rydal Hall, Westmorland from 1688-1701 (Kendal: Cumberland and Westmorland Antiquarian and Archaeological Society, 2001).

${ }^{90}$ Thomas Turner seems to have done the same. See for example David Vaisey ed., The Diary of Thomas Turner, 1754-1765 (Oxford: Oxford University Press, 1984), 297, where he paid over proceeds from five briefs.

${ }^{91}$ Winchester ed., Diary of Isaac Fletcher, 102 and passim.

${ }^{92}$ Winchester ed., Diary of Isaac Fletcher, 130. 
${ }^{93}$ The Elizabethan protections clustered in May and November, the main transition points in the agricultural year.

${ }^{94}$ McIntosh, Poor Relief, 172-3.

${ }^{95}$ Bewes, Church Briefs, 49. Kitching, 'Fire Disasters', 183-4.

${ }^{96}$ Henry Fishwick ed., The History of the Parish of Kirkham, in the County of Lancaster (Manchester: Chetham Society, 1874), 108.

${ }^{97}$ Barmby ed., Churchwardens accounts ... in the Diocese of Durham, $76-7$ (this example is from Pittington in 1619). Receipts are, however, recorded at St Nicholas, Durham in 1665. Ibid., 220-1. Shaw and Shaw eds., Thirty Men of Kirkham, 18 and passim.

${ }^{98}$ Brushfield, 'Devonshire Briefs', 614 . In contrast the median collection range was $f 1-2$ at St Margaret's, Westminster, 1644-1793, the mode $f 2-5$.

${ }^{99}$ Specific legislation covered cymorthau, which the crown saw as potentially a way lords might abuse entrenched traditions of neighbourly hospitality and generosity. H. Ellis ed., Registrum Vulgariter Nuncupatum 'The Record of Caernarvon' (London: Record Commission, 1838), 238, 296. David Lewis, 'The Court of the President and Council of Wales and the Marches from 1478 to 1575', y Cymmrodor 12 (1897), 42-7. Caroline A. J. Skeel, The Council in the Marches of Wales (London: H. Rees, 1904), 39, 65, 107. Geraint D. Owen, Elizabethan Wales: the Social Scene (Cardiff: University of Wales Press, 1964), 27-8. Ralph A. Griffiths, 'Gruffydd ap Nicholas and the Fall of the House of Lancaster', Welsh History Review 2 (1965), 217. J. Gwynfor Jones, Aspects of Religious Life in Wales, c.1536-1660: Leadership, Opinion and the Local Community (Aberystwyth: Centre for Educational Studies, Faculty of Education, University of Wales, 2003), 89. NA E 163/11/34 (1533). Peter Roberts, 'Elizabethan Players and Minstrels and the Legislation of 1572 Against Retainers and Vagabonds', in Anthony Fletcher and Peter Roberts eds., Religion, Culture and Society in Early Modern Britain (Cambridge: Cambridge University Press, 1994), 29-55. In 1537 Rowland Lee, bishop of Coventry and Lichfield and Lord President of the Council in the Marches, wrote to Thomas Cromwell complaining about the licence granted to George Mathewe, a Glamorgan gentleman, 'to aske and demaunde suche thinges as his kynsfolkes, alies and other his ffrendes and neighbours will ffrely of their goode myndes departe with 
him by way of Commortha' anywhere in Wales. Lewis, 'Court of the Council', 42-3. Cromwell seems to have responded positively to the request to curb this grant.

${ }^{100}$ G. Nesta Evans, Religion and Politics in Mid-Eighteenth Century Anglesey (Cardiff: University of Wales Press, 1953), 185. For examples of collections in another contemporary parish see J. Fisher, 'The Religious and Social Life of Former Days in the Vale of Clwyd, as Illustrated by the Parish Records', Archaeologia Cambrensis $6^{\text {th }}$ series 6 (1906), 160-2. ${ }^{101}$ Quoted in Kitching, 'Fire Disasters', 179. Wales and the northern counties of England also dragged their feet over the Nantwich fire collection of 1583. Ibid., 184.

102 George Herbert, A Priest to the Temple, or, the Country Parson his Character, and Rule of Holy Life (London: T. Maxey, 1652), 77-8.

${ }^{103} \mathrm{HL}$ Ellesmere 7410. One reply to the renewed appeal is a long letter of excuse from Wenllog (Wenlog or Wenlooge), Monmouthshire, citing their contribution to this cause in 1634 as well as help given to plague victims at nearby Abergavenny, bridges, repairs to sea defences (ongoing since 1606), and losses from a legal dispute over their main cash generator (butter). HL Ellesmere 7420.

104 Margaret Gray, The History of Bury Lancashire from 1660 to 1876 (Bury: Bury Times, 1970), 125. C. Flynn-Hughes, 'Aspects of Poor Law Administration and Policy in Anglesey, 1834-1848', Transactions of the Anglesey Antiquarian Society (1950), 71-9. Alun C. Davies, 'The Old Poor Law in an Industrializing Parish: Aberdare, 1818-1836', Welsh History Review 8 (1977), 285-311. Nicholas C. Edsall, The Anti-Poor Law Movement, 1834-44 (Manchester: Manchester University Press, 1971), 129, 132. R. N. Thompson, 'The Working of the Poor Law Amendment Act in Cumbria, 1836-1871', Northern History 15 (1979), 117-37. Larry Patriquin, Agrarian Capitalism and Poor Relief in England, 1500-1800: Rethinking the Origins of the Welfare State (Basingstoke: Palgrave, 2007), 144-5.

${ }^{105}$ Vaisey ed., Diary of Thomas Turner, 315-16. Canon law (confirmed by 4 \& 5 Anne, c. 14) only required clergy to collect in church.

${ }^{106}$ Vaisey ed., Diary of Thomas Turner, xxviii-xxix. There were 66 inhabited houses in 1811, suggesting that the 1757 collectors expected all householders to contribute something. 
${ }^{107}$ Henry B. Wheatley ed., The Diary of Samuel Pepys 8 vols (London: G. Bell and Sons, 1952), vol. 2, 57 and n. As many as 58 different briefs may have been issued during 1660-1. Brushfield, 'Devonshire Briefs', 608. Most of the London briefs 1659-1722 were for rebuilding after fire. Harris, 'London, Charity Briefs', 101.

${ }^{108}$ C.S.P. Domestic 1633-1634 (London: Public Record Office, 1863), 216.

${ }^{109}$ HL Ellesmere 4553.

${ }^{110}$ Doe ed., The Diary of James Clegg, 179, 197.

${ }^{111}$ Brushfield, 'Devonshire Briefs', 607. 9 Geo. IV, c. 42.

112 Bewes, Church Briefs, 269-305, lists those located in central archives from 1642. Slack, Poverty and Policy, 166.

${ }^{113}$ Fisher, 'Religious and Social Life', 160-1.

${ }^{114}$ M. E. Kuper, 'Seven Volumes of Dalston Parish Registers', Transactions of the Cumberland \& Westmorland Antiquarian \& Archaeological Society 7 (1884), 182-4, 195. Angus J. L. Winchester and Mary Wane eds., Thomas Denton, A Perambulation of Cumberland, 1687-1688 (Woodbridge: Boydell Press, 2003), 255. Winchester ed., Diary of Isaac Fletcher, index 'church briefs'. The Secretary of the Lord Chancellor recommended in 1804 that a 'Register of Briefs' should be kept in every parish. Walford, 'Kings' Briefs', 52.

${ }^{115}$ Brushfield, 'Devonshire Briefs', 606-711.

${ }^{116}$ Works of Jonathan Swift, vol. 16, 307-8.

${ }^{117}$ J. Swift, 'Memoirs of P. P., Clerk to this Parish', in The Works of Mr Alexander Pope, in Prose 2 vols (London: J. and P. Knapton, C. Bathurst, and R. Dodsley, 1737-41), vol. 2, 263. M. H. Port, Six Hundred New Churches: the Church Building Commission, 1818-1856 (London: S.P.C.K., 1961), 6. Ben-Amos, Culture of Giving, 339.

${ }^{118}$ Ben-Amos, Culture of Giving, 338. Ping, 'Raising Funds', 59.

${ }^{119}$ HL Ellesmere 3721.

${ }^{120}$ NLS Crawford CB.69, 73. 
${ }^{121}$ Dot Reid, 'Thomas Aquinas and Viscount Stair: the Influence of Scholastic Moral Theology on Stair's Account of Restitution and Recompense', Journal of Legal History 29 (2008), 194-

5.

122 McIntosh, Poor Relief, 279.

${ }^{123}$ See for example Brushfield, 'Devonshire Briefs', 618.

${ }^{124}$ Albert Kiralfy, 'History of the Law of Personal Guarantee (Suretyship) in England Since 1500', in Les sûretés personnelles. Pt.2 Moyen Âge et Temps Modernes (Brussels: Recueils de la Société Jean Bodin pour I'Histoire Comparative des Institutions, Tome XXIX, 1971), 399-424. A. W. B. Simpson, A History of the Common Law of Contract: the Rise of the Action of Assumpsit (Oxford: Oxford University Press, 1987). Pledging and oaths may have declined, but there were still problems of enforcing trust. Craig Muldrew, The Economy of Obligation (Basingstoke: Macmillan, 1998). John Smail, 'Credit, Risk, and Honor in Eighteenth-Century Commerce', Journal of British Studies 44 (2005), 439-56.

125 J. J. N. McGurk, 'Casualties and Welfare Measures for the Sick and Wounded of the Nine Years War in Ireland, 1593-1602', Journal of the Society for Army Historical Research 68, 275 (1990), 188-204. Veterans too were dealt with by other means. McIntosh, Poor Relief, 2767. Joanna Innes, Inferior Politics. Social Problems and Social Policies in Eighteenth-Century Britain (Oxford: Oxford University Press, 2009), 48-77.

\footnotetext{
${ }^{126}$ McIntosh, Poor Relief, $106-7$.

127 Julia F. Merritt, 'Puritans, Laudians, and the Phenomenon of Church-Building in Jacobean London', Historical Journal 41 (1998), 948-9.
}

${ }^{128}$ According to Wallace Notestein, ales produced profits of $£ 10-15$ a year to churchwardens of the early sixteenth century, but seldom more than $£ 4-5$ a century later. However, the provenance of the sums is not footnoted. Wallace Notestein, The English People on the Eve of Colonization, 1603-1630 (New York: Harper \& Bros., 1954), 244-5. In 1553 Marston, Oxfordshire's profit was 20s and Pyrton's 44s $8 \mathrm{~d}$ a few years later. F. W. Weaver and G. N. Clark eds., Churchwardens' Accounts of Marston, Spelsbury, Pyrton (Oxford: Oxfordshire Record Society, 1925), 18, 74. In 1600, Wootton in Devon netted $f 12$ 14s 1d from a 'King 
Ale'. Sidney and Beatrice Webb, English Local Government: English Poor Law History, part 1. The Old Poor Law (London: Longmans, Green, 1927), 13n.

${ }^{129}$ Thomson, Early Tudor Church, 271.

${ }^{130}$ Peter H. Greenfield, 'Drama outside London after 1540', in Jane Milling and Peter Thomson eds., The Cambridge History of British Theatre. Volume I: Origins to 1660 (Cambridge: Cambridge University Press, 2004), 182. David Underdown, Fire from Heaven: Life in an English Town in the Seventeenth Century (London: Fontana, 1993), 125-8, 228-9, 250-1, is impressed by the sums raised in early- and mid-seventeenth-century Dorchester. ${ }^{131}$ Archer, 'Charity of Early Modern Londoners', 239.

132 McIntosh, Poor Relief, 162.

${ }^{133}$ Sarah Lloyd, 'Pleasing Spectacles and Elegant Dinners: Conviviality, Benevolence, and Charity Anniversaries in Eighteenth-Century London', Journal of British Studies 41 (2002), 23-57.

${ }^{134}$ HL Ellesmere 3151.

135 Blunt ed., Book of Common Prayer, part 2, 171. Claire S. Schen, Charity and Lay Piety in Reformation London, 1500-1620 (Aldershot, 2002), 203-4, 235. John Charles Cox, Three Centuries of Derbyshire Annals as Illustrated by the Records of the Quarter Sessions 2 vols (London: Bemrose and Sons, 1890), vol. 1, 378-89. Beck, 'Church Briefs', 165-7.

${ }^{136}$ HC Debates 22 May 1828, vol. 19, 873-4. Harris, 'London, Charity Briefs', 104. The Church Building Society was established in 1818 after 58 Geo. III c. 45 tried to deal with the chronic problem of funding building. Clarke, Eighteenth-Century Church, 96-103. 